The International Journal Of Engineering And Science (IJES)

|| Volume || 6 || Issue || 2 || Pages || PP 17-26 || 2017 ||

ISSN (e): $2319-1813 \operatorname{ISSN}$ (p): $2319-1805$

THE IJES

\title{
Equilibrium and Kinetics Adsorption of Cadmium and Lead Ions from Aqueous Solution Using Bamboo Based Activated Carbon
}

\author{
Udeh, N.U ${ }^{1}$, Agunwamba, J.C ${ }^{2}$ \\ ${ }^{I}$ Department of Civil and Environmental Engineering, University of Port Harcourt, Nigeria. \\ ${ }^{2}$ Department of Civil and Environmental Engineering, University of Nigeria Nuskka, Nigeria.
}

\begin{abstract}
Sourcing cheap adsorbents for the treatment of waste water is imperative for local environments. The adsorption of cadmium $(\mathrm{Cd})$ and lead $(\mathrm{Pb})$ from aqueous solution onto bamboo activated carbon prepared by chemical activation with $\mathrm{ZnCl}_{2}$ was investigated. The unwashed chemical activated bamboo carbon (UCABC) achieved up to $87.81 \%$ and $96.45 \%$ removal of $\mathrm{Cd}$ and $\mathrm{Pb}$ at $\mathrm{pH}-5$ and 11 , respectively. Removal equilibrium was attained within $1 \mathrm{hr}$ and $2.5 \mathrm{hrs}$ for $\mathrm{Cd}$ and $\mathrm{Pb}$, respectively. The $\mathrm{Cd}$ and $\mathrm{Pb}$ adsorption increased with adsorbent dosage decrease while removal rate (\%) increased with $\mathrm{Cd}$ and $\mathrm{Pb}$ concentration. Adsorption isotherm of $C d$ and $P b$ onto UCABC was determined and correlated with four isotherm models (Langmuir, Freundlich, Temkin and Hills). The equilibrium data fitted into Freundlich $C d\left(R^{2}=0.9873, S S E=0.045\right), P b$ $\left(R^{2}=0.9903, S S E=0.051\right) ;$ Temkin $C d\left(R^{2}=0.9730, S S E=0.052\right), P b\left(R^{2}=0.9079, S S E=0.056\right) ;$ Hills $C d$ $\left(R^{2}=0.9961, S S E=0.048\right), P b\left(R^{2}=0.9183, S S E=0.053\right)$ and Langmuir $C d\left(R^{2}=0.9653, S S E=0.302\right), P b$ $\left(R^{2}=0.9899, S S E=0.136\right)$ isotherms. The Freundlich fitting showed isotherm adsorption capacity constants $K_{f}$ $=7.843$ and $5.098(\mathrm{mg} / \mathrm{g})$ for $\mathrm{Cd}$ and $\mathrm{Pb}$, respectively. Furthermore, their adsorption kinetics correlated with the Pseudo-first order, Pseudo-second order and Intra-particle diffusion models and could be best described by the Pseudo-second order equation, suggesting chemisorptions as the limiting process. This study demonstrated that the UCABC can remove $\mathrm{Cd}^{2+}$ and $\mathrm{Pb}^{+}$ions from aqueous solution to avert expensive commercial adsorbents.
\end{abstract}

Keywords: Adsorbents, Bamboo activated carbon, Adsorption, Isotherms, Kinetics.

Date of Submission: 21 November $2016 \longrightarrow$ Date of Accepted: 09 February 2017

Nomenclature

a Gradient of linear plots

$\mathrm{A}_{\mathrm{t}} \quad$ Temkin isotherm constant relating to equilibrium binding energy $(\mathrm{L} / \mathrm{g})$

$b_{t} \quad$ Temkin isotherm constant relating to heat of adsorption.

UCABC Unwashed Chemical Activated Bamboo Carbon.

$\mathrm{Cal} \mathrm{q}_{\mathrm{e}} \quad$ Calculated adsorbate

concentration at equilibrium $(\mathrm{mg} / \mathrm{g})$

$\mathrm{C}_{\mathrm{e}} \quad$ Equilibrium concentration $(\mathrm{mg} / \mathrm{l})$

$\mathrm{C}_{\mathrm{o}} \quad$ Initial concentration of adsorbate $(\mathrm{mg} / \mathrm{l})$.

$\mathrm{C}_{\mathrm{t}} \quad$ Concentration of adsorbate at any time $\mathrm{t}$ $(\mathrm{mg} / \mathrm{l})$

Exp $\mathrm{q}_{\mathrm{e}} \quad$ Experimental adsorbate equilibrium conc. $(\mathrm{mg} / \mathrm{g})$

$\mathrm{h} \quad$ Initial adsorption rate ( $\mathrm{mg} / \mathrm{g} / \mathrm{mins})$

$\mathrm{K}$ Langmuir constant relating to rate of adsorption

$\mathrm{K}_{\mathrm{D}} \quad$ Hills constant

$\mathrm{K}_{\mathrm{f}} \quad$ Freundlich isotherm adsorption capacity constant

$\mathrm{k}_{\mathrm{id}} \quad$ Intra particle diffusion rate constant $\left(\mathrm{min}^{-1}\right)$

$\mathrm{K}_{\mathrm{p} 1} \quad$ First order rate constant (mg/mins)

$\mathrm{K}_{\mathrm{p} 2} \quad$ Second order rate constant ( $\left.\mathrm{mg} / \mathrm{mins}\right)$

$\mathrm{m} \quad$ Mass of adsorbent $(\mathrm{g})$

$\mathrm{N} \quad$ Number of data points.

$\mathrm{n} \quad$ Freundlich isotherm constant relating to adsorption intensity

$\mathrm{nH} \quad$ Hills coefficient describing cooperativity

$\mathrm{q}_{\mathrm{e}} \quad$ Mass of solute adsorbed per unit mass of adsorbed (mg/g)

qo Maximum monolayer adsorption capacity (mg/g)

$\mathrm{q}_{\mathrm{t}} \quad$ Amount adsorbed at time $\mathrm{t}(\mathrm{mg} / \mathrm{g})$

$\mathrm{q}_{\mathrm{SH}}$ Hills equilibrium constant relating to $\max$ uptake saturation $(\mathrm{mg} / \mathrm{l})$

$\mathrm{R}$ Fraction of the amount adsorbed

$\mathrm{R}^{2}$ Coefficient of determination

$\mathrm{R}_{\mathrm{L}}$ Dimensionless separation factor

$\mathrm{T}$ Absolute temperature (Kelvin) $(\mathrm{K})$

$\mathrm{t}$ Contact time (min)

$\mathrm{V}$ Experimental volume of wastewater (liters) 


\section{INTRODUCTION}

Land and water bodies are polluted with all kinds of chemicals and toxic substances which are discharged from industrial and domestic effluents. The indiscriminate release of heavy metals via wastewater into the environment without proper treatment has resulted in a total pollution of the environment. This has caused many water bodies receiving loads of pollutants that exceed the maximum permissible limit designed to protect the environment thereby, causing ineffectiveness of purification systems which may lead to accumulation of toxic products in the receiving water bodies with potentially serious consequences on the ecosystem (Beg et al, 2001). The presence of these heavy metals in the environment has led to many environmental problems since most of them are toxic, carcinogenic and persistence in nature. For example, the lead poisoning in Zamfara State, Nigeria in 2010 which claimed hundreds of lives clearly attests to the detrimental effect of heavy metals in the environment [On line www.iccon.org.ng/index. last assessed Jan. 2016]. Also, 1950 Japanese Scientists reported that more than 45 people died as a result of consuming fishes caught in Minamata Bay, which were found to contain high levels of mercury (Watanabe and Satoh, 1996). Therefore, the treatment of polluted industrial wastewater remains a topic of global concern. At least 20 metals are classified as toxic, in which lead and cadmium are among and many of these are emitted into the environment in quantities that pose risk to human health (Dwari et al, 2004).

Adsorption has been extensively studied as an effective method for removing a wide range of hazardous materials such as heavy metals and dyes from aqueous solutions. The most widely used adsorbent for separation of pollutants is activated carbon. However, commercial activated carbon is very expensive thus, efforts has been geared toward the use of agricultural by products as raw material for manufacturing activated carbon. Bamboo, an abundant natural resource, can be used to produce activated carbon (Hameed et al, 2006; Keith et al, 2005; Evbuomwan et al, 2013; Mahanim et al, 2011; Nwabane and Mordi, 2009). The use of natural material as raw materials for manufacturing activated carbon is advantageous as these raw materials are renewable and potentially less expensive. The objective of this study is to use bamboo activated carbon to remove cadmium and lead from aqueous solution. The equilibrium and kinetic studies were conducted to understand the nature and mechanism of the adsorption process.

\section{EXPERIMENTAL}

\subsection{Preparation of Bamboo Activated Carbon}

The Bamboo sticks (Bamboosoidae Grasses L) used in this study is the dominant bamboo in Nigeria found in the rain forest belt (Forestry Department, Food and Agriculture Organization, 2005). Fully matured Bamboo sticks were cut into $(2-4 \mathrm{~cm})$ sizes, washed, outdoor dried and then processed in laboratory. The bamboo samples were chemically activated using $\mathrm{ZnCl}_{2}$ (80\% purity) at impregnation ratio of 1:2, then carbonized in a muffle furnace at $500^{\circ} \mathrm{C}$ for $3 \mathrm{hrs}$ and grinded into powder. The bamboo activated carbon was not washed (to remove the activating chemical) rather they were passed through a set of sieves $(50,150,250$ and $425 \mu \mathrm{m})$ to obtain different particle sizes for experimental tests. This set of samples was referred to as Unwashed Chemical Activated Bamboo Carbon (UCABC).

\subsection{Optimum Conditions for Adsorption of $\mathrm{Cd}$ and $\mathrm{Pb}$ onto UCABC.}

Wastewater samples were simulated in the laboratory by mixing $\mathrm{CdCl}_{2} \cdot 2_{2}^{\frac{1}{-}} \mathrm{H}_{2} \mathrm{O}$ salt and $\left(\mathrm{Pb}\left(\mathrm{NO}_{3}\right)_{2}\right)$ salt in distilled water to obtain the desired initial concentrations. All the chemicals used were of analytical grade. Batch adsorption studies were performed to determine the optimum conditions for the removal of $\mathrm{Cd}$ and $\mathrm{Pb}$ from the simulated wastewater. Effects of carbon dosage were studied at $\mathrm{pH} 7$ with different adsorbent doses (1, 2, 3, 4 and $5 \mathrm{~g}$ ) and initial adsorbate concentration $(20 \mathrm{mg} / \mathrm{l})$ and agitating for $1 \mathrm{~h}$. Effects of initial adsorbate conc. were studied at various concentration of $\mathrm{Cd}$ and $\mathrm{Pb}(10,20,30,40$ and $50 \mathrm{mg} / \mathrm{l})$ but using the optimum adsorbent dosage and other experimental conditions remained the same. Effects of adsorbate $\mathrm{pH}$ were studied by adjusting the adsorbate $\mathrm{pH}(3,5,7,9$ and 11) using $0.1 \mathrm{M} \mathrm{NaOH}$ or HCL and then using optimum dosage and concentration while other experimental conditions remained the same. The effects of agitation time were investigated for $0.5,1.0,1.5,2.0,2.5$ and $3.0 \mathrm{hrs}$ using optimum dosage, concentration and $\mathrm{pH}$. The effects of particle size were conducted at various particle sizes $(50,150,250$ and $425 \mu \mathrm{m})$ using the optimum dosage, concentration, $\mathrm{pH}$ and time. At the end of adsorption period, the various samples were filtered through Whatman filter paper (\#542) and the filtrates were analyzed for residual concentrations of $\mathrm{Cd}$ and $\mathrm{Pb}$ using Atomic Adsorption Spectrometer (AAS) (model Spectr AA 55B, Agilent Technologies, USA). The adsorption efficiency (Equation 1) of the test carbons was used as criterion for determining optimum conditions.

$\%$ Removal $=\frac{\left(\mathrm{C}_{\mathrm{D}}-\mathrm{C}_{\mathrm{T}}\right)}{\mathrm{C}_{\mathrm{o}}} \times 100 \%$ 


\subsection{Equilibrium Adsorption Studies}

The equilibrium adsorption studies were conducted at $25^{\circ} \mathrm{C}$ using optimum condition for $\mathrm{Cd}$ and $\mathrm{Pb}$ at fixed initial adsorbate conc. and varying adsorbent doses, to investigate the sorption capacity of UCABC. For Cd, $50 \mathrm{ml}$ of simulated wastewater samples of $50 \mathrm{mg} / 1(\mathrm{pH} \mathrm{5})$ were measured into 5 different plastic containers and specified adsorbent doses $(0.2,0.4,0.6,0.8$ and $1.0 \mathrm{~g})$ of $50 \mu \mathrm{m}$ were added to each of the plastic containers. The mixtures were agitated on a mechanical shaker for $1 \mathrm{hr}$. The procedures were replicated for $\mathrm{Pb}$ using $\mathrm{pH} 11$, particle size $(250-425 \mu \mathrm{m})$ and agitation time of $2.5 \mathrm{hrs}$. At the end of the adsorption period, the mixtures were filtered and analyzed for residual $\mathrm{Cd}$ and $\mathrm{Pb}$ by $\mathrm{AAS}$. The equilibrium adsorption capacity $\left(\mathrm{q}_{\mathrm{e}}\right)$ of the adsorbent was obtained using Equation (2)

$$
\mathrm{q}_{\mathrm{e}}=\frac{\left(\mathrm{C}_{\mathrm{q}}-\mathrm{C}_{\mathrm{e}}\right)}{\mathrm{M}} \mathrm{V}
$$

\subsection{Adsorption Kinetics}

The adsorption kinetics of $\mathrm{Cd}$ and $\mathrm{Pb}$ was processed at various intervals using two initial concentrations $(50 \mathrm{mg} / \mathrm{l}$ and $100 \mathrm{mg} / \mathrm{l})$. For $\mathrm{Cd}, 0.2 \mathrm{~g}$ of $\operatorname{UCABC}(50 \mu \mathrm{m})$ were mixed with $50 \mathrm{ml}$ of $\mathrm{Cd}$ solution $(\mathrm{pH} 5)$ and then attached to a mechanical shaker. The samples were agitated and then taken at 5, 10, 20, 30, 40, 50, 60, 70, 80, 100 and $120 \mathrm{mins}$ intervals and filtered. For $\mathrm{Pb}, 0.2 \mathrm{~g}$ of UCABC $(250-425 \mu \mathrm{m}$ size $)$ was mixed with $50 \mathrm{ml}$ of $\mathrm{Pb}$ solution (pH 11) and the attached to a mechanical shaker. The samples were agitated and taken at 10, 20, 40, 60, 80, 100, 120,140, 160 and 180mins intervals and filtered. The filtrates were analyzed for residual concentrations of Cd and $\mathrm{Pb}$ by $\mathrm{AAS}$ The adsorption capacity of the adsorbents at preset time $\mathrm{t}, \mathrm{q}_{\mathrm{t}}$, was obtained from Equation (3).

$$
\mathrm{q}_{\mathrm{t}}=\frac{\left(\mathrm{C}_{\mathrm{D}}-\mathrm{C}_{\mathrm{t}}\right)}{\mathrm{M}} \mathrm{V}
$$

\subsection{Optimum Condition for Adsorption}

\section{RESULTS AND DISCUSSION}

The effect of adsorbent doses on $\mathrm{Cd}$ and $\mathrm{Pb}$ adsorption onto UCABC revealed that adsorption decreased with adsorbent dosage (Figure 1), while the results in Figure 2 showed that higher initial concentration of the adsorbate gave higher removal rate (\%) with an optimum removal efficiency of $82.62 \%$ and $92.82 \%$ for $\mathrm{Cd}$ and $\mathrm{Pb}$, respectively.

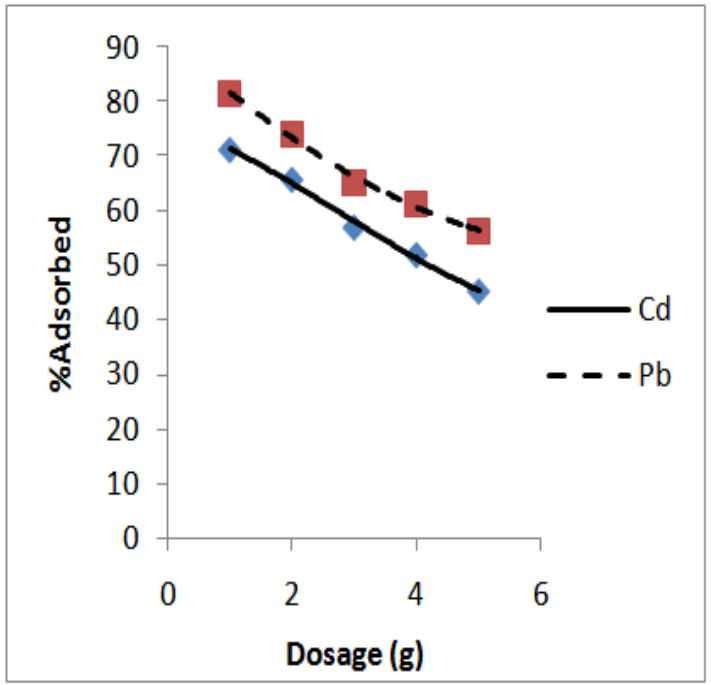

Figure 1: Effects of Adsorbent dosage $\mathrm{UCABC}$ on Adsorption of $\mathrm{Cd}$ and $\mathrm{Pb}$

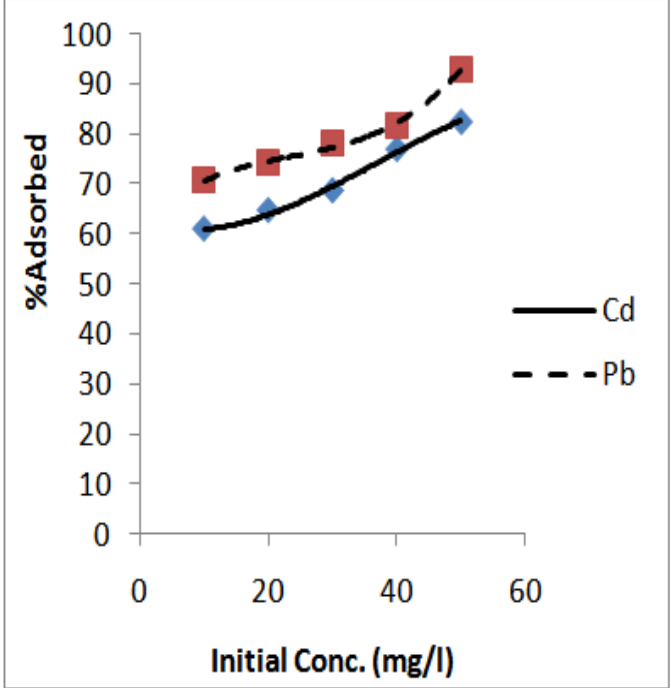

Figure 2: Effects of Initial concentration of $\mathrm{Cd}$ and $\mathrm{Pb}$ on Adsorption onto UCABC

The effect of $\mathrm{pH}$ on adsorption showed that removal efficiency (\%) of $\mathrm{Cd}$ decreased while that of $\mathrm{Pb}$ increased with increase in $\mathrm{pH}$-value. High removal efficiency of $87.81 \%$ at $\mathrm{pH} 5$ was observed for $\mathrm{Cd}$, while $96.45 \%$ was observed for $\mathrm{Pb}$ at $\mathrm{pH} 11$ (Figure 3). Furthermore, the removal efficiency increased with agitation time and attained equilibrium in $1 \mathrm{~h}$ for $\mathrm{Cd}$ and $2.5 \mathrm{hrs}$ for $\mathrm{Pb}$ (Figure 4 ). 


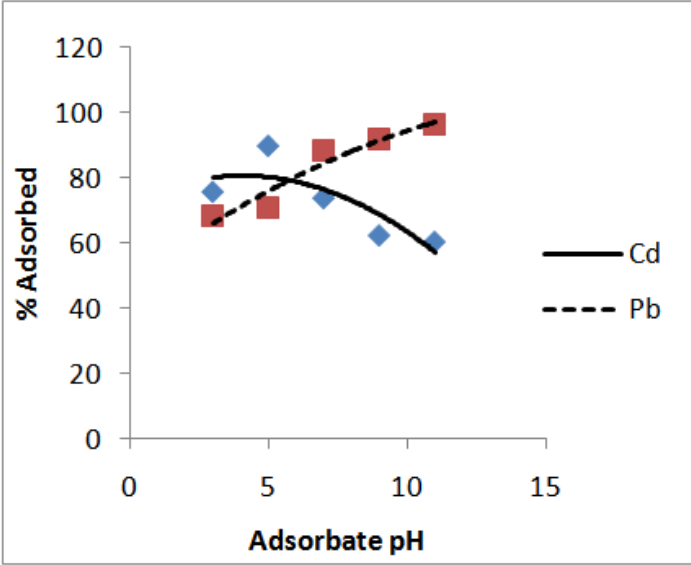

Figure 3: Effects of Adsorbate $\mathrm{pH}$ on Adsorption of $\mathrm{Cd}$ and $\mathrm{Pb}$ onto $\mathrm{UCABC}$

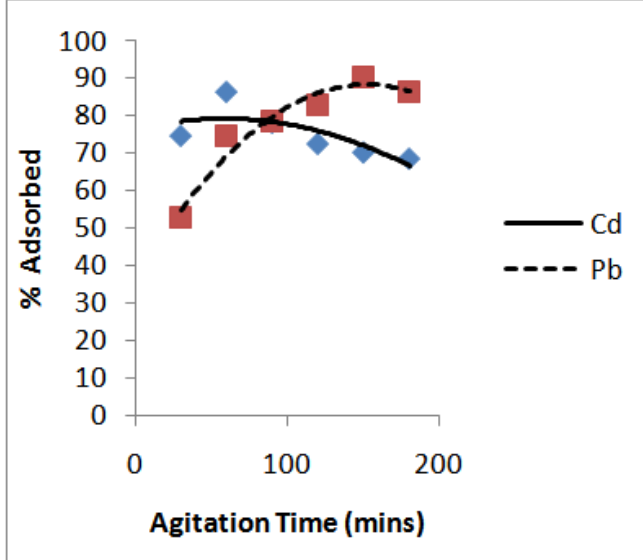

Figure 4: Effects of Agitation Time on Adsorption of $\mathrm{Cd}$ and $\mathrm{Pb}$ onto $\mathrm{UCABC}$

\subsection{Adsorption Isotherms}

Adsorption isotherms were used to describe the interactions of solutes with adsorbents with a view to optimizing adsorbent dosage. The equilibrium data from $\mathrm{Cd}$ and $\mathrm{Pb}$ adsorption onto UCABC were modelled using Langmuir, Freundlich, Temkin and Hills isotherm models in order to obtain the best fit.

\subsubsection{Langmuir Isotherm}

Langmuir isotherm is based on following assumptions: (1) that the surface of the adsorbent is homogenous (all the adsorption sites are equivalent). (2) Adsorbed molecules do not interact. (3) All adsorption occurs through the same mechanism. (4) At the maximum adsorption, only a monolayer is formed. Mathematically, the Langmuir adsorption isotherm is expressed in Equation (4):

$q_{e}=\frac{q_{0} K_{2}}{1+\mathrm{KC}_{\mathrm{e}}}$

(4)

The linear form of Langmuir's isotherm model is given in Equation 5:

$\frac{C_{g}}{q_{g}}=\frac{1}{q_{0} K}+\frac{C_{g}}{q_{0}}$

(5)

Linear plot of $\frac{c_{\varepsilon}}{q_{s}}$ against $C_{e}$ gives slope $=\frac{1}{q_{e}}$ and intercept $=\frac{1}{q_{0} k}$

The correlation of experimental data with Langmuir equation gave high correlation coefficient $\left(\mathrm{R}^{2}=0.9653\right.$ and $0.9899)$ for $\mathrm{Cd}$ and $\mathrm{Pb}$ respectively. The Langmuir adsorption capacity $\left(\mathrm{q}_{\mathrm{o}}\right)$ was 1.912 and $2.023(\mathrm{mg} / \mathrm{g})$, the energy of adsorption $(\mathrm{K})$ was -0.884 and $-1.965\left(\mathrm{mg}^{-1}\right)$ for $\mathrm{Cd}$ and $\mathrm{Pb}$ respectively The Langmuir dimensionless equilibrium parameter $\mathrm{R}_{\mathrm{L}}$ calculated from Equation 6. were given as -0.018 and -0.01 for $\mathrm{Cd}$ and $\mathrm{Pb}$ respectively. $R_{L}=\frac{1}{1+K C_{0}}$

(6)

Observe that the value of $R_{L}$ indicates the type of the isotherm to be either unfavorable $\left(R_{L}>1\right)$, linear $\left(R_{L}=1\right)$, favourable $\left(0<\mathrm{R}_{\mathrm{L}}<1\right)$ or irreversible $\left(\mathrm{R}_{\mathrm{L}}=0\right)$.

\subsubsection{Freundlich Isotherm}

The Freundlich isotherm, which is based on the equilibrium relationship between heterogeneous surfaces, assumes interaction between the adsorbed molecules and multilayer formation on the surface of the adsorbent with an exponential distribution of the heat of adsorption. The Freundlich equation (Freundlich, 1906) is expressed in Equation (7):

$$
\mathrm{q}_{\mathrm{e}}=\mathrm{K}_{\mathrm{f}} \mathrm{C}_{\mathrm{e}}^{\frac{1}{\mathrm{n}}}
$$

Linear form of Freundlich equation is given in Equation (8).

$$
\log \left(q_{e}\right)=\log K_{f}+\frac{1}{n} \log C_{e} \text {. }
$$

(8)

Linear plot of $\log \mathbf{q}_{\mathbf{e}}$ against $\log \mathbf{C}_{\mathbf{e}}$ gives slope $=1 / \mathrm{n}$ and intercept $=\log \mathbf{K}_{\mathrm{f}}$. 
Correlation of experimental data with Freundlich model also gave high correlation coefficients $\left(\mathrm{R}^{2}=0.9873\right.$ and 0.9903) for both $\mathrm{Cd}$ and $\mathrm{Pb}$ adsorption as shown in Figs. 5 and 6. The Freundlich adsorption capacity $\left(\mathrm{K}_{\mathrm{f}}\right)$ was as 7.843 and $5.098(\mathrm{mg} / \mathrm{g}$ ) for $\mathrm{Cd}$ and $\mathrm{Pb}$ respectively indicating good adsorption capacity for UCABC (Amuda and Ibrahim, 2006). The $1 / \mathrm{n}$ values obtained were -0.595 and -0.462 for $\mathrm{Cd}$ and $\mathrm{Pb}$ respectively. Note that the value for $1 / n$ below one implies chemisorptions process while $1 / n$ above one is indicative of cooperative adsorption (Haghseresht and Lu, 1998; Foo and Hameed, 2009; Fytianos et al, 2000).

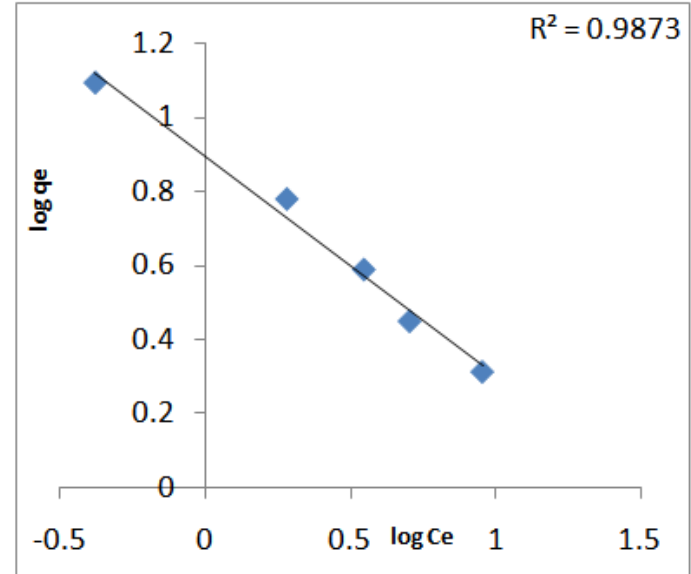

Figure 5: Freundlich Isotherm for the Adsorption of Cd onto UCABC.

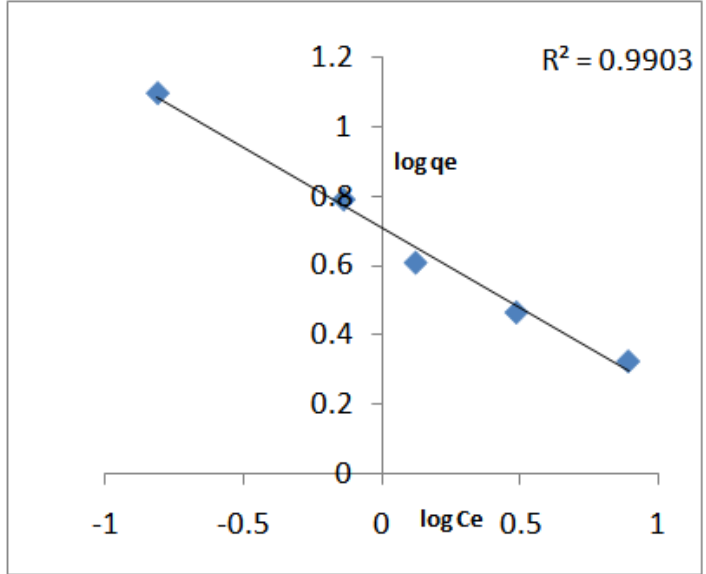

Figure 6: Freundlich Isotherm for the Adsorption of $\mathrm{Pb}$ onto UCABC.

\subsubsection{Temkin Isotherm}

The Temkin isotherm model assumes that the heat of adsorption (function of temperature) of all the molecules in the layer decreases linearly with coverage due to adsorbent-adsorbate interactions (Aharoni and Ungarish, 1977; Foo and Hameed, 2010). Also, the model assumes that the adsorption is characterized by a uniform distribution of the binding energies, up to some maximum binding energy. Temkin isotherm is represented in equation (9):

$$
q_{e}=\frac{R T}{b_{T}} \log A_{T} C_{e}
$$

The linearized form of this model is given in Equation (10):

$$
q_{e}=\frac{R T}{b_{T}} \log A_{T}+\frac{R T}{b_{T}} \log C_{e}
$$

(10)

A plot of $q_{e}$ versus $\log C_{e}$ enables the determination of the isotherm constants $b_{T}$ and $A_{T}$ from the slope and intercept respectively. Correlation of experimental data with Temkin model also gave high correlation coefficients $\left(\mathrm{R}^{2}=0.973\right.$ and 0.9079$)$ for $\mathrm{Cd}$ and $\mathrm{Pb}$, respectively as shown in Figures 7 and 8 . The Temkin isotherm parameters $\left(b_{t}=-306.74\right.$ and -403.70$)$ and $\left(A_{t}=0.897\right.$ and 0.097$)$ relates to the equilibrium binging energy and heat of adsorption for $\mathrm{Cd}$ and $\mathrm{Pb}$, respectively.
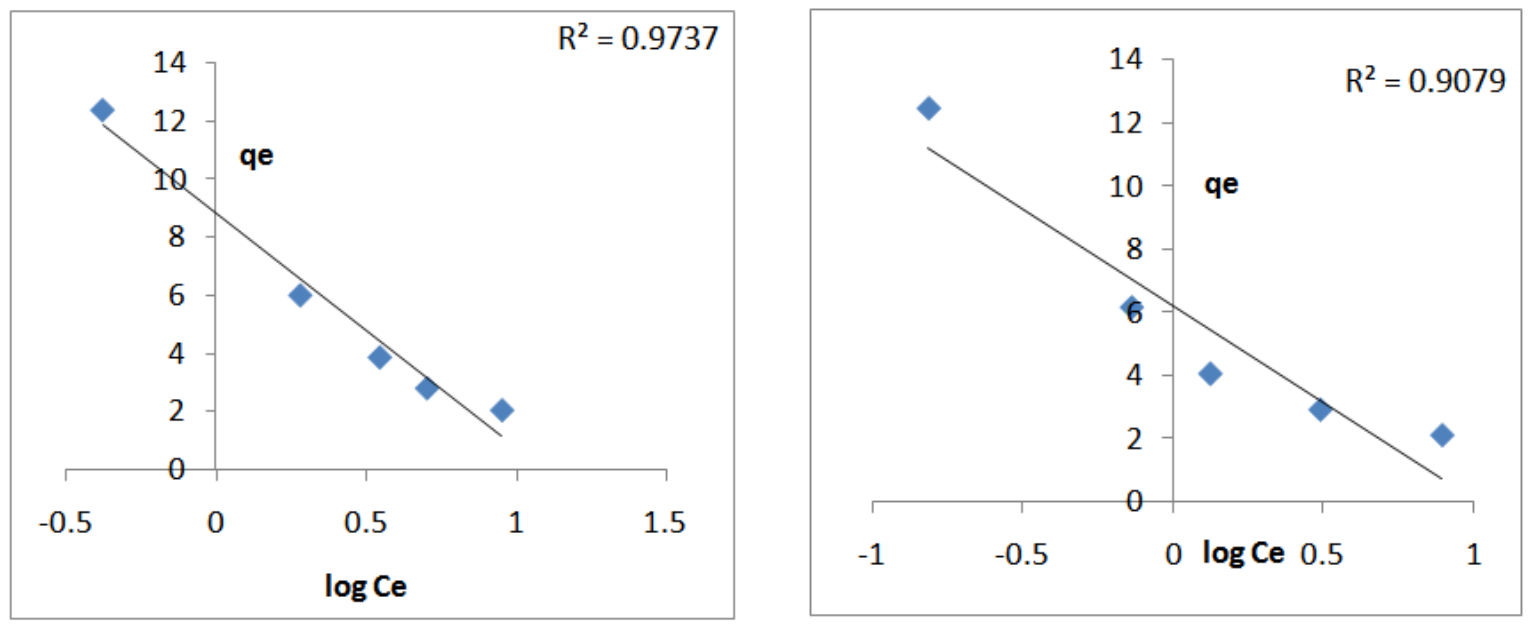
Figure 7: Temkin Isotherm for the Adsorption of Cd onto UCABC
Figure 8: Temkin Isotherm for the Adsorption of $\mathrm{Pb}$ onto UCABC

\subsubsection{Hills Isotherm}

Hills isotherm equation (Hill, 1910) was postulated to describe the binding of different species onto homogeneous substrates. The model assumes that adsorption is a cooperative phenomenon, with the ligand binding ability at one site on the macromolecule and this may influence different binding sites on the same macromolecule (Ringot et al, 2007; Foo and Hameed 2010). Hills isotherm model is represented in Equation (11):

$$
q_{e}=\frac{q_{S H} c_{\Sigma}^{n H}}{k_{D}+C_{\varepsilon}^{n H}}
$$

The linearized form of the model is given in Equation (12):

$$
\log \left(\frac{q_{s}}{q_{s H}-q_{\varepsilon}}\right)=n H \log C_{\theta}-\log K_{D}
$$

A plot of $\log \left(\frac{q_{\varepsilon}}{q_{S H}-q_{\varepsilon}}\right)$ versus $\log C_{e}$ enables the determination of the isotherm constants $n H$ and $K_{D}$ from the slope and intercept respectively. The correlation of experimental data with Hills model equations also gave high correlation coefficient $\left(\mathrm{R}^{2}=0.9961\right.$ and $\left.\mathrm{R}^{2}=0.9183\right)$ for both $\mathrm{Cd}$ and $\mathrm{Pb}$ respectively as shown in Figures 7 and 8. The Hills isotherm parameters were given as ( $\mathrm{qsH}=18$ and 14$)(\mathrm{nH}=-0.949$ and 0.974$)$ and $\left(\mathrm{K}_{\mathrm{D}}=0.936\right.$ and 0.9183) for $\mathrm{Cd}$ and $\mathrm{Pb}$ adsorption respectively.

\subsection{Model Verification}

To verify the authenticity of these isotherm models for the adsorption of $\mathrm{Cd}$ and $\mathrm{Pb}$, interpolated and extrapolated $\mathrm{C}_{\mathrm{e}}$ values from the equilibrium adsorption were used to calculate the Exp $\mathrm{q}_{\mathrm{e}}$ and Cal $\mathrm{q}_{\mathrm{e}}$ values for model verification. The calculated isotherm parameters were fitted into the isotherm model equations to get the calculated $\mathrm{q}_{\mathrm{e}}$ values. The plots of Exp $\mathrm{q}_{\mathrm{e}}$ and Cal $\mathrm{q}_{\mathrm{e}}$ against dosage were presented in Figures 11 to 16.

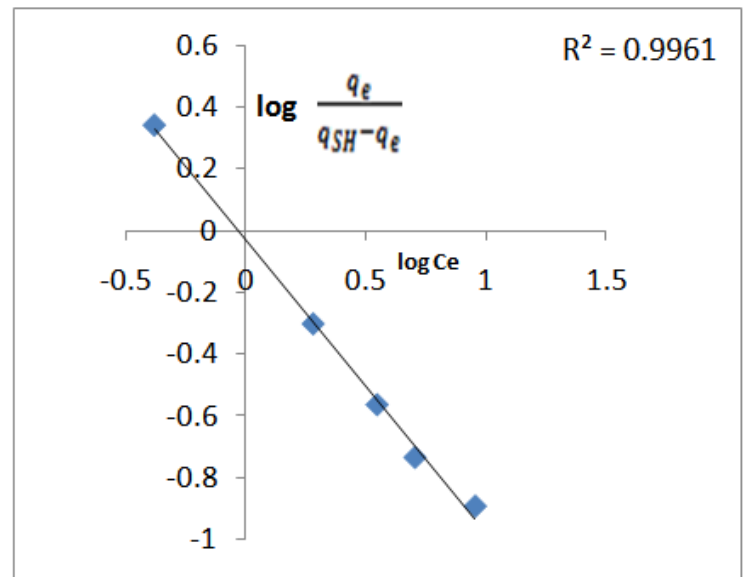

Figure 9: Hills Isotherm for Adsorption of Cd onto UCABC.

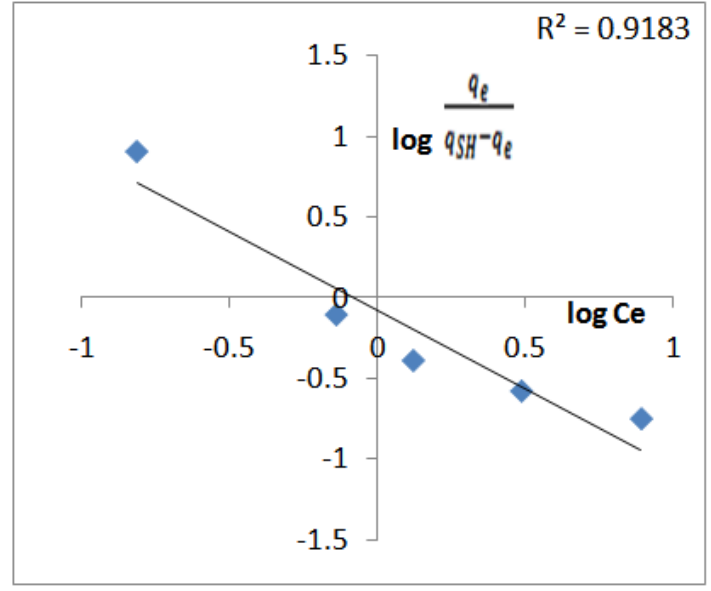

Figure 10: Hills Isotherm for Adsorption of $\mathrm{Pb}$ onto $\mathrm{UCABC}$. 


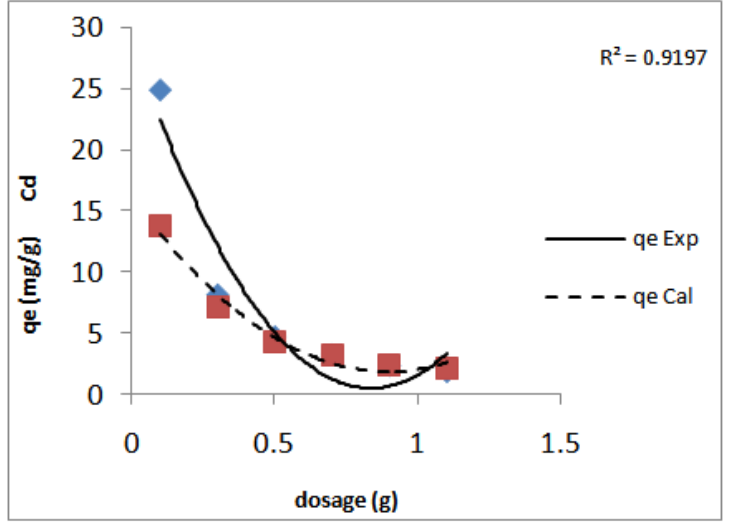

Figure 11: Freundlich Exp and $\mathrm{Cal} \mathrm{q}_{\mathrm{e}}$ for Adsorption of Cd onto UCABC.

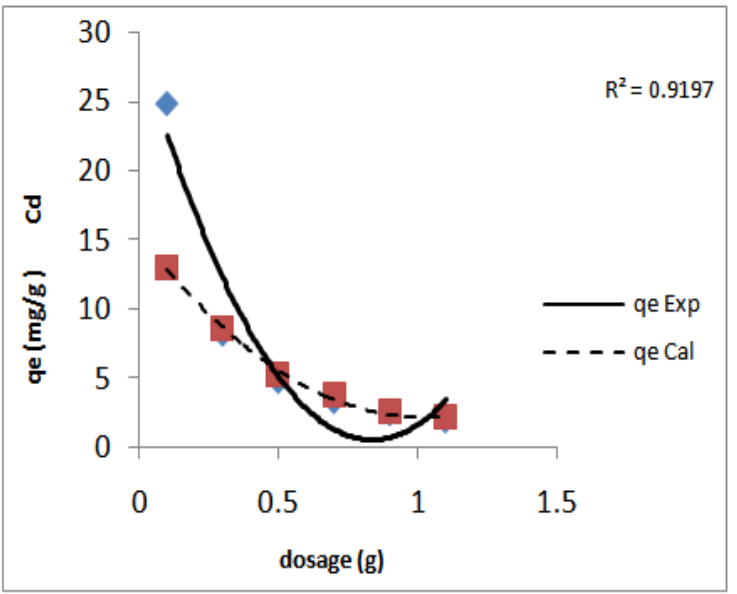

Figure 13: Hills Exp and $\mathrm{Cal} \mathrm{q}_{\mathrm{e}}$ for Adsorption of Cd onto UCABC.

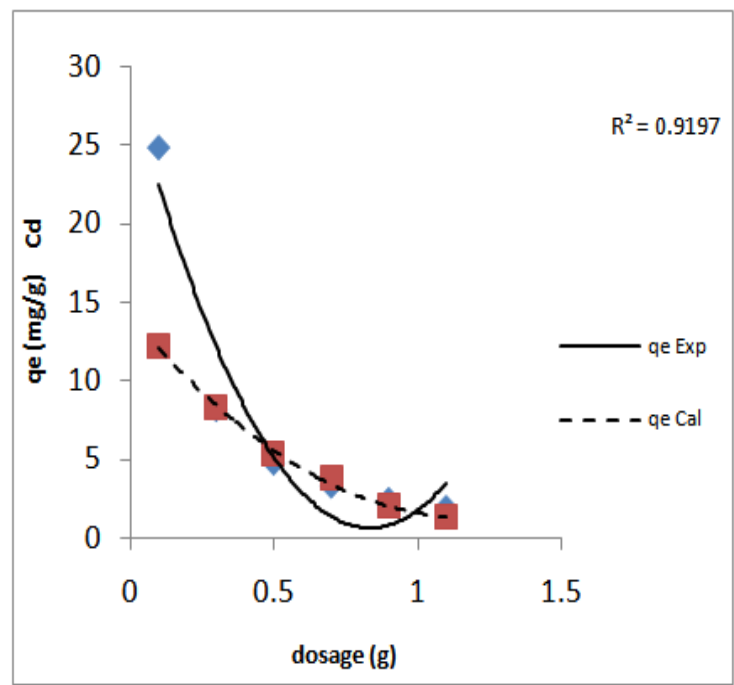

Figure 15: Temkin Exp and $\mathrm{Cal} \mathrm{q}_{\mathrm{e}}$ for Adsorption of Cd onto UCABC.

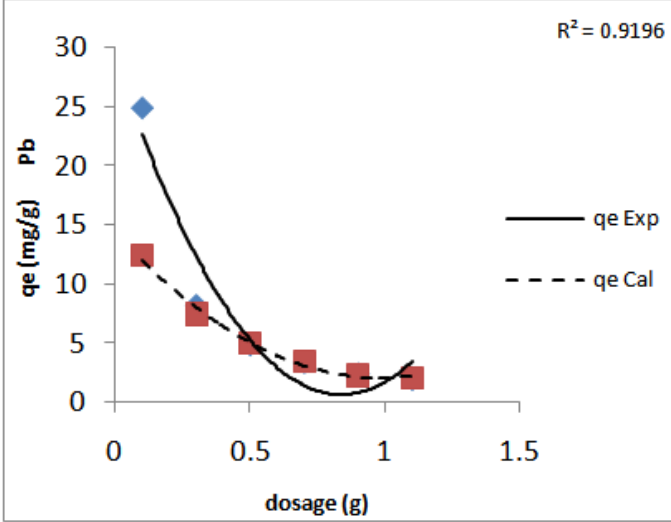

Figure 12: Freundlich Exp and Cal $\mathrm{q}_{\mathrm{e}}$ for Adsorption of $\mathrm{Pb}$ onto UCABC.

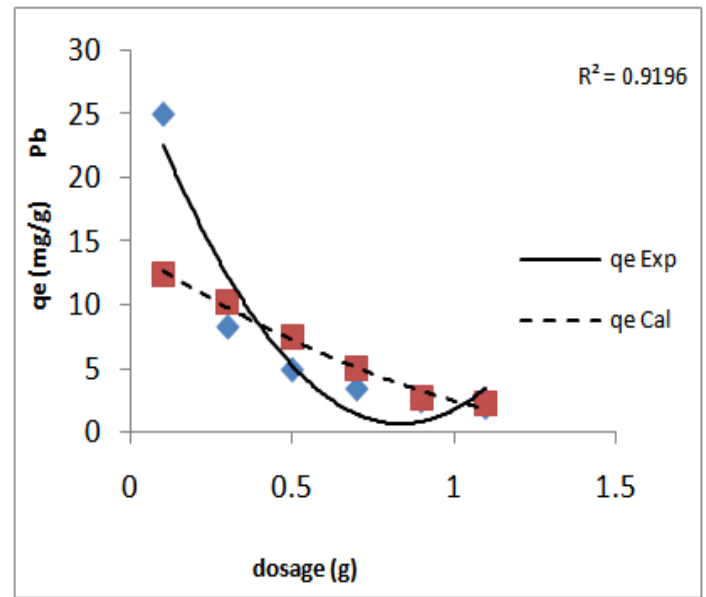

Figure 14: Hills Exp and $\mathrm{Cal} \mathrm{q}_{\mathrm{e}}$ for Adsorption of $\mathrm{Pb}$ onto UCABC.

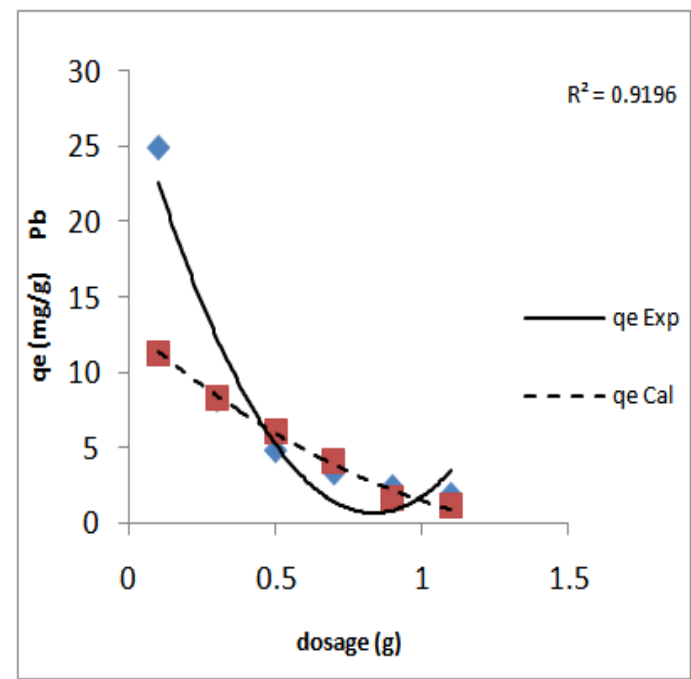

Figure 16: Temkin Exp and $\mathrm{Cal} \mathrm{q}_{\mathrm{e}}$ for Adsorption of $\mathrm{Pb}$ onto UCABC.

From the plots, it was observed that Exp $\mathrm{q}_{\mathrm{e}}$ values correlated with the Cal $\mathrm{q}_{\mathrm{e}}$ values for Freundlich, Temkin and Hills models but do not correspond with Langmuir models despite the high correlation coefficients. However, the applicability of the isotherm models for the adsorption of $\mathrm{Cd}$ and $\mathrm{Pb}$ was further verified.

\subsection{Test for Isotherm Models}


The applicability of these isotherm models was further verified through the sum of error squares (SSE, \%) calculated from Equation 13: Note that the higher the value of $\mathrm{R}^{2}$ and the lower the value of SSE, the better will be the goodness of fit.

$\operatorname{SSE}(\%)=\sqrt{\frac{\sum\left(q_{\varepsilon_{c} \varepsilon x p}-q_{q_{c} a \mathrm{l}}\right)^{2}}{N}}$

The sum of error squares was calculated from the values of Exp $\mathrm{q}_{\mathrm{e}}$ and Cal $\mathrm{q}_{\mathrm{e}}$ values using the Excel software. Results of the test for validity of each isotherm model shown in Table 1 revealed that Freundlich isotherm model had the smallest SSE value $(0.045 \%)$ and $(0.054 \%)$ for $\mathrm{Cd}$ and $\mathrm{Pb}$ adsorption respectively. From these results, the adsorption of $\mathrm{Cd}$ and $\mathrm{Pb}$ onto UCABC fitted well into Freundlich, Hills and Temkin model but could be best described by Freundlich isotherm indicating chemisorptions adsorption with multilayer formation on heterogeneous surface of UCABC. Similar observations were made by Nwabane and Mordi, 2009; Ademiluyi et al, 2009).

Table 1: SSE (\%) Values for the Adsorption of $\mathrm{Cd}$ and $\mathrm{Pb}$ onto UCABC

\begin{tabular}{|l|l|l|}
\hline Equilibrium Models & SSE\% Cd & SSE\% Pb \\
\hline Langmuir isotherm & 0.302 & 0.136 \\
Freundlich isotherm & 0.045 & 0.051 \\
Temkin isotherm & 0.052 & 0.056 \\
Hills isothrem & 0.048 & 0.053 \\
\hline
\end{tabular}

\subsection{Adsorption Kinetics}

The adsorption kinetics was investigated to understand the mechanism of adsorption process in terms of the order of rate constant. The rate of adsorption was analyzed using pseudo-first order, pseudo second order and intra particle diffusion model equations.

\subsubsection{Pseudo First Order Model}

The pseudo first order equation is given in Equation 14:

$\frac{\mathrm{dq}}{\mathrm{dt}}=\mathrm{K}_{\mathrm{p} 1}\left(\mathrm{q}_{\mathrm{e}}-\mathrm{q}_{\mathrm{t}}\right)$

After integration and applying boundary conditions, $\mathrm{t}=0$ to $\mathrm{t}=\mathrm{t}$ and $\mathrm{q}_{\mathrm{t}}=0$ to $\mathrm{q}_{\mathrm{t}}=\mathrm{q}_{\mathrm{t}}$; the integrated form of equation (14) is given in Equation 15:

$\log \left(q_{e}-q_{t}\right)=\log \left(q_{e}\right)-k_{p 1} t$

The values of $\log \left(\mathrm{q}_{\mathrm{e}}-\mathrm{q}_{\mathrm{t}}\right)$ from experimental data were linearly correlated with $\mathbf{t}$ and the values of $\mathbf{k}_{\mathbf{p} \mathbf{1}}$, and $\mathbf{q}_{\mathbf{e}}$ were determined from the slope and intercept of the plots respectively. The $\mathrm{R}^{2}$ values from the plots gave poor correlation and the Exp and Cal qe values were significantly different as shown in Table 2. These suggest that the adsorption data fitted poorly to pseudo first order kinetics. Also, low $\mathrm{k}_{\mathrm{p} 1}$ values were observed for $\mathrm{Cd}$ and $\mathrm{Pb}$ removal indicating lower rate of adsorption. Generally, the higher the value of $\mathrm{k}_{\mathrm{p} 1}$, the greater the adsorption while the lower the Exp qe value the better the adsorption (Igwe and Abia, 2007).

Table 2: Kinetic Parameters of Equilibrium Adsorption $\left(\mathrm{q}_{\mathrm{e}}\right)$ for $\mathrm{Cd}$ and $\mathrm{Pb}$ onto UCABC

\begin{tabular}{|c|c|c|c|c|c|c|c|c|c|c|c|c|c|}
\hline Metals & $\mathrm{C}_{\mathrm{o}}$ & \multicolumn{5}{|c|}{ Pseudo First Order } & \multicolumn{4}{|c|}{ Pseudo Second Order } & \multicolumn{3}{|c|}{ Intra Particle Diffusion } \\
\hline \multirow{3}{*}{$\mathrm{Cd}$} & \multirow{3}{*}{$\begin{array}{l}50 \\
100\end{array}$} & $\begin{array}{l}\text { Exp. } \\
q_{\mathrm{e}}\end{array}$ & $\begin{array}{l}\text { Cal } \\
q_{\mathrm{e}}\end{array}$ & $\mathrm{K}_{\mathrm{p} 1}$ & $\mathrm{R}^{2}$ & $\begin{array}{l}\text { SSE } \\
(\%)\end{array}$ & $\mathrm{Cal} \mathrm{q}$ & $\mathrm{K}_{\mathrm{p} 2}$ & $\mathrm{R}^{2}$ & $\begin{array}{l}\text { SSE } \\
(\%)\end{array}$ & $\mathrm{K}_{\mathrm{id}}$ & A & $\mathrm{R}^{2}$ \\
\hline & & 11.5 & 0.45 & 0.001 & 0.003 & 0.17 & 10.79 & -0.13 & 0.9981 & 0.007 & 93.35 & -0.015 & 0.361 \\
\hline & & 22.0 & 0.37 & 0.003 & 0.014 & & 21.23 & -0.08 & 0.9981 & & 85.27 & 0.004 & 0.036 \\
\hline $\mathrm{Pb}$ & $\begin{array}{l}50 \\
100\end{array}$ & $\begin{array}{l}12.4 \\
24.0\end{array}$ & $\begin{array}{l}0.12 \\
0.34\end{array}$ & $\begin{array}{l}0.004 \\
0.002\end{array}$ & $\begin{array}{l}0.235 \\
0.039\end{array}$ & 0.19 & $\begin{array}{l}11.78 \\
22.88\end{array}$ & $\begin{array}{l}0.042 \\
-0.08\end{array}$ & $\begin{array}{l}0.9993 \\
0.9987\end{array}$ & 0.009 & $\begin{array}{l}100.55 \\
91.14\end{array}$ & $\begin{array}{l}-0.008 \\
0.0067\end{array}$ & $\begin{array}{l}0.169 \\
0.057\end{array}$ \\
\hline
\end{tabular}

\subsubsection{Pseudo-Second Order Model}

The pseudo-second-order equation expressed in Equation 16, predicts the behaviour of the adsorbent over the whole range of data and it is in agreement with chemisorption being the rate controlling step (Ho and McKay, 1999):

$\frac{\mathrm{dq}}{\mathrm{dt}}=\mathrm{k}_{\mathrm{p} 2}\left(\mathrm{q}_{\mathrm{e}}-\mathrm{q}_{\mathrm{t}}\right)^{2}$

Integrating Equation 16 at the same boundary conditions $\mathrm{t}=0$ to $\mathrm{t}=\mathrm{t}$ and $\mathrm{qt}=0$ to $\mathrm{qt}=\mathrm{qt}$, the integrated form is given in Equation (17):

$\frac{1}{q_{\mathrm{e}}-\mathrm{q}_{\mathrm{t}}}=\frac{1}{\mathrm{q}_{\mathrm{e}}+\mathrm{k}_{\mathrm{p} 2}}$ 
Equation (17) is the integrated rate law for a pseudo second order reaction and rearranging in linear form is expressed in Equation 18:

$\frac{\mathrm{t}}{\mathrm{q}_{\mathrm{t}}}=\frac{1}{\mathrm{k}_{\mathrm{p} 2} \mathrm{q}_{\mathrm{e}}^{2}}+\frac{1}{\mathrm{q}_{\mathrm{e}}} \mathrm{t}$

(18)

The pseudo second order plots for the adsorption of $\mathrm{Cd}$ and $\mathrm{Pb}$ onto UCABC at two different concentrations were presented in Figures 17 and 18. The corresponding second order kinetic constants and the correlation coefficients were given in Table 2. A correlation was observed between the experimental $\mathrm{q}_{\mathrm{e}}$ and the calculated $\mathrm{q}_{\mathrm{e}}$ values with the $\mathrm{R}^{2}$ values ranging from 0.9981 and 0.9993 . Thus, the adsorption of $\mathrm{Cd}$ and $\mathrm{Pb}$ onto UCABC fitted well into pseudo second order kinetics. Furthermore, it was observed that the equilibrium adsorption capacity, $\mathrm{q}_{\mathrm{e}}$ increased with increase in initial $\mathrm{Cd}$ and $\mathrm{Pb}$ concentrations. The same tend was observed by (Akpen et al, 2011).

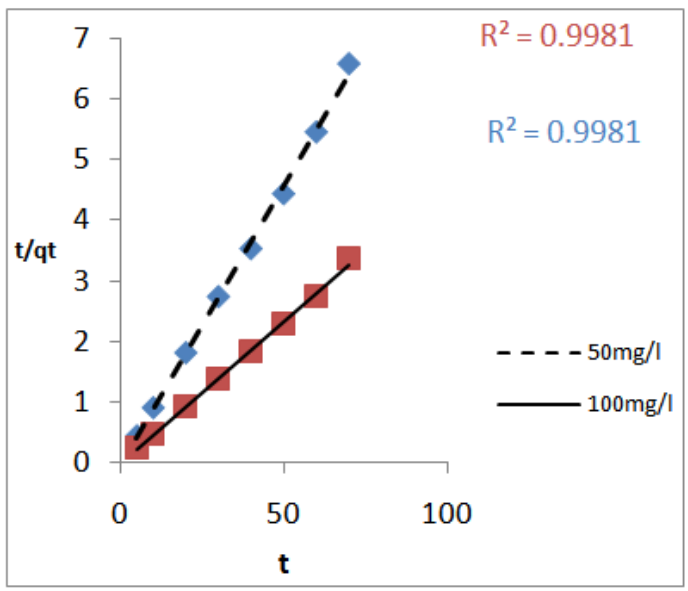

Figure 17: Pseudo-second-order kinetics for Cd adsorption onto UCABC.

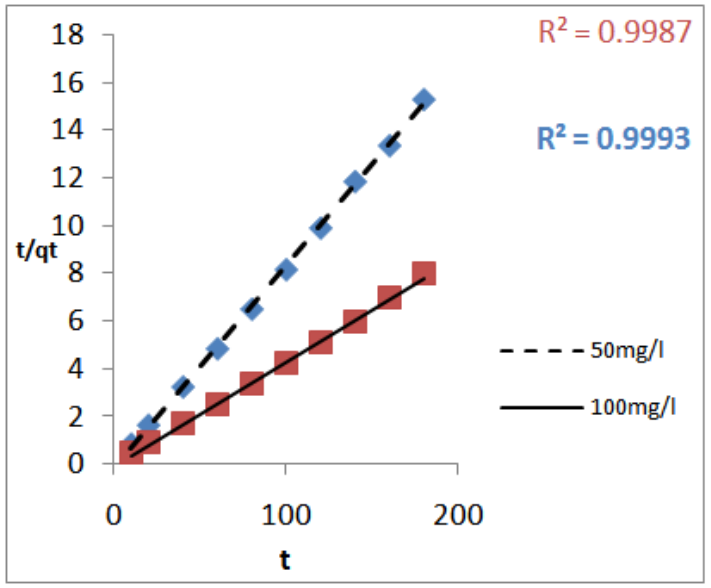

Figure 18: Pseudo second order kinetics for $\mathrm{Pb}$ adsorption onto $\mathrm{UCABC}$

\subsubsection{Intra-Particle Diffusion Model}

Intra-particle diffusion model (Weber and Morris, 1963) is expressed in Equation (18):

$\mathrm{R}=\mathrm{K}_{\mathrm{id}}(\mathrm{t})^{\mathrm{a}}$

The linearized form is expressed in Equation (20) as:

$\log R=\log K_{i d}+a \log (t)$

The plot of $\log \mathbf{R}$ vs. $\log \mathbf{t}$ gives a linear plot from which the values of ' $\mathbf{a}$ ' and $\mathbf{K}_{\text {id }}$ would be determined from the slope and intercept respectively. If Intra Particle diffusion occurs, then a plot of $\log \mathrm{R}$ against $\log \mathrm{t}$ will give a linear plot which will pass through the origin if Intra Particle Diffusion was the only rate limiting parameter controlling the process.

However, the linear plots from this study did not pass through the origin. The deviation from the origin may be due to the variation of mass transfer in the initial and final stages of adsorption (Sivakumar and Palanisamy, 2009). This indicates that intra particle diffusion was not the sole rate controlling step involved in the adsorption of $\mathrm{Cd}$ and $\mathrm{Pb}$ onto UCABC. The Intra Particle diffusion rate, $\mathrm{K}_{\mathrm{id}}$ and the coefficients of determination $\left(\mathrm{R}^{2}\right)$ were presented in Table 2. In general, high $\mathrm{K}_{\mathrm{id}}$ values indicate a better adsorption mechanism, which is related to an improved bounding between the adsorbent particles and adsorbates (Demirbas et al, 2004).

\subsubsection{Test of Kinetic Models}

The applicability of these kinetic models was verified using SSE, \% (Equation 13). The Exp $\mathrm{q}_{\mathrm{e}}$ and Cal $\mathrm{q}_{\mathrm{e}}$ values were used to calculate the SSE using the Excel ${ }^{\circledR}$ platform and the results were presented in Tables 2 . Results of the test for validity of each Kinetic model showed that pseudo second order kinetic model had the smallest SSE value of $0.007 \%$ and $0.009 \%$ for $\mathrm{Cd}$ and $\mathrm{Pb}$ adsorption respectively. Note that the higher the value of $\mathrm{R}^{2}$ and the lower the value of SSE, the better will be the goodness of fit. From these results, the adsorption of $\mathrm{Cd}$ and $\mathrm{Pb}$ onto UCABC was best described by the Pseudo Second Order Kinetic Model. Similar observations have been reported by (Hameed et al 206; Foo and Hameed, 2010; Wang et al, 2010).

\section{CONCLUSION}


This study demonstrated the adsorptive capacity of Unwashed Chemical Activated Bamboo Carbon (UCABC) in the removal of $\mathrm{Cd}$ and $\mathrm{Pb}$ from wastewater. The UCABC achieved up to $87.81 \%$ and $96.45 \%$ removal efficiency for $\mathrm{Cd}$ and $\mathrm{Pb}$, respectively. The amount of $\mathrm{Cd}$ and $\mathrm{Pb}$ adsorbed increased with adsorbent dosage decrease; while the removal rate (\%) increased with increase in initial $\mathrm{Cd}$ and $\mathrm{Pb}$ concentration. The adsorption behaviour of $\mathrm{Cd}$ and $\mathrm{Pb}$ was described by Freundlich, Temkin and Hills Isotherms with a best fit in Freundlich equation indicating multilayer adsorption on heterogeneous surface. The kinetic data followed pseudo second order model suggesting that chemisorptions may be the rate limiting step in the adsorption process and it may involve the sharing or exchange of electrons between adsorbent (UCABC) and adsorbates (Cd and $\mathrm{Pb})$.

\section{REFERENCES}

[1]. Ademiluyi, F.T., Amadi, S.A., Amakama and Nimisingha, J. 2009. Adsorption and Treatment of Organic Contaminants using Activated Carbon from Waste Nigeria Bamboo. [J]. J. Appl. Sci. Environ. Manage. 13 (3): 39-47.

[2]. Aharoni, C. and Ungarish, M. 1977. Kinetics of Activated Chemisorptions, Part 2: Theoretical Models. [J]. J. Chem. Soc., Faraday Trans. 1, 73, 456-464. DOI: 10.1039/F19777300456

[3]. Akpen, G.D., Nwaogazie, I.L. and Leton, T.G. 2011. Optimum Conditions for the Removal of Colour from Wastewater by Mango Seed Shell Based Activated Carbon. [J]. Indian J. of Sci. and Tech. 4 (8): 890-894.

[4]. Amuda, S. and Ibrahim, A.O. 2006. Industrial Wastewater Treatment using Natural Material as Adsorbent. [J]. Afr. J. Biotechnol., 5 (16), 1483-1487.

[5]. Beg, M.U., Al-Muzaini, S., Saeed, T. et al., 2001. Chemical Contamination and Toxicity of Sediment from a Coastal Area Receiving Industrial Effluents in Kuwait. - Arch. Environ Contam. Toxicol. 41 (3): 289-297. DOI: 10.1007/s002440010251.

[6]. Demirbas, E., Kobya, M., Senturk, E. and Ozkan, T. 2004. Adsorption kinetics for the Removal of Chromium (VI) from Aqueous Solutions on the Activated Carbons prepared from Agricultural Wastes. [J]. Water. SA., 30, (4) 533-539.

[7]. Dwari, R.K, Biswas, M.N and Meikap, B.C. 2004. Performance Characteristics of Particles of Sand-FCC and Fly Ash in a Novel Hydrocyclone [J]. Chem. Engr. Sci., 59 (3): 671-684.

[8]. Evbuomwan, B.O, Abutu, A.S and Ezeh, C.P. 2013. The Effects of Carbonization Temperature on Some Physicochemical Properties of Bamboo Based Activated Carbon By Potassium Hydroxide (KOH) Activation. [J]. J. Physi. Sci. 3 (5): 187-191.

[9]. Foo, K.Y. and Hameed, B.H. 2009. A Short Review of Activated Carbon Assisted Electro Sorption Process: An Overview, Current Stage and Future Prospects. [J]. J. Hazard. Mater.. 171, (2-3) 552-559.

[10]. Foo, K.Y. and Hameed, B.H. 2010. Insights into Modelling of Adsorption Isotherm Systems. [J]. Chem. Engr. J. 156 (1): 2-10.

[11]. Forestry Department, Food and Agriculture Organization. 2005. UN Global Forest Resources Assessment; Nigeria Country Report on Bamboo Resources, 4.

[12]. Freundlich, H.M.F. 1906. Overview of the Adsorption in Solution. [J]. J. Physical Chem. 57: $385-471$.

[13]. Fytianos, K., Voudrias, E. and Kokkalis, E. 2000. Sorption-Desorption Behaviour of 2,4-dichlorophenol by Marine Sediment. [J]. Chemosphere, $40(1): 3-6$.

[14]. Haghseresht, F. and Lu, G. 1998. Adsorption Characteristics of Phenolic Compound onto Coal-Reject-Derived Adsorbents. [J]. Energy Fuels. 12 (6):1100- 1107. DOI: 10.1021/ef9801165

[15]. Hameed, B.H, Din, A.T.M and Ahmad, A.L. 2006. Adsorption of Methylene Blue onto Bamboo-Based Activated Carbon: Kinetics and Equilibrium Studies. [J]. J. Hazard. Mater. 141 (3): 819 - 825.

[16]. Hill, A.V. 1910. The Possible Effects of the Aggregation of the Molecules of Haemoglobin on its Dissociation Curves. [J]. J. Physiol. 40 iv - vii. DOI: 10.113/jphysiol.1910.sp001386.

[17]. Ho, Y.S. and McKay, G. 1999. Pseudo-Second Order Model for Sorption Processes. [J]. Process Biochem., 34, (5): 451-465.

[18]. Igwe, J.C. and Abia, A.A. 2007. Adsorption Isotherm Studies of Cadmium, Lead and Zinc II ions Bioremediation from Aqueous Solution using Unmodified and EDTA-modified Maize Cob. [J]. Ecletica Quimica, 32 (1): 33-42.

[19]. Institute of Charted Chemists of Nigeria (ICCON), 2015. Zamfara Lead Poisoning Crisis - The Story', Accessed January; Retrieved from: http://www.iccon.org.ng/index.php?option=com_content\&task=view\&id=168\&Itemid=14

[20]. Keith, K.H, Choy, J.P and McKay, G. 2005. Production of Activated Carbon from Bamboo Scaffolding Waste - Process Design, Evaluation and Sensitivity analysis. [J]. Chem. Engr. J. 109 (1-3): 147 -165.

[21]. Mahanim, S.M.A., Asma, I.W., Rafidah, J. et al., 2011. Production of Activated Carbon from Industrial Bamboo Wastes. [J]. J. Trop. Forest Sci. 23 (4): 417-424.

[22]. Nwabanne, J.T. and Mordi, M.I. 2009. Equilibrium Uptake and Sorption Dynamics for the Removal of Basic Dye using Bamboo. [J]. Afr. J. Biotechnol. 8 (8), 1555-1559.

[23]. Ringot, D., Lerzy, B., Chaplain, K. et al. 2007. In vitro Biosorption of Ochratoxin A on the yeast industry by-products: comparison of isotherm models. [J]. Bioresour. Technol. 98 (9): 1812-1821.

[24]. Sivakumar, P. and Palanisamy, P.N. 2009. Adsorption Studies of Basic Red 29 by a Non-Conventional Activated Carbon Prepared from Euphorbia Antiquorum L. [J]. Int. J. of Chem. Tech. Res. 1, (3): 502.

[25]. Wang, F., Wang, W. and Ma, J. 2010. Adsorption of Cadmium II ions from Aqueous Solution by a new Low Cost Adsorbent, Bamboo Charcoal. [J]. J. Hazard. Mater. 177,(1-3): 300- 306.

[26]. Watanabe, C and Satoh, H., 1996. Evolution of Our Understanding of Methyl-Mercury as a Health Threat, [J]. Environ. Health Persp. 104 (2): 367-379.

[27]. Weber, W.J. and Morris, J.C. 1963. Kinetics of Adsorption on Carbon from Solution. [J]. J. of Sanit. Eng. Div. Am. Soc. Civil Eng., 89, (1) 31-60. 